\title{
A "LUA" MUSICAL DE CRUZ E SOUSA
}

\section{Zélia de Almeida Cardoso}

Tanto já se discutiu sobre a musicalidade de poesia simbolista que poderia parecer até mesmo óbvio continuar a insistir em tal matéria.

A releitura, entretanto, dos poemas de Broquéis suscitou-nos o desejo de relembrar o assunto.

Verlaine, ao propor como elemento primeiro da poesia "la musique avant toute chose", reconduziu a arte poética a suas origens, estreitando novamente a ligação que tivera, nos primórdios, com a música. Seguindo a "liçãa" do mestre, os simbolistas valorizaram os ritmos mais melódicos, escolherem com cuidado as palavras mais sonoras, utilizaram-se, com abundância, de todos aqueles recursos fônicos que, no dizer dos formalistas russos (1), compõem a "orquestração" da obra literária: os esquemas rítmicos, a repetição de qualidades de som idênticas ou associadas, os fonemas expressivos, as imagens acústicas. Com isso, além de relevarem, segundo seu propósito, o mundo transcendente, apresentaram-nos também um mundo musical.

Cruz e Sousa foi, sem dúvida, dentre os nossos poetas, o que mais de perto viveu e seguiu os preceitos da estética simbolista.

Referindo-se a ele, na História da Literatura Brasileira, sem ter ainda o distanciamento cronológico suficiente para, numa visão em perspectiva, conferir ao artista sua devida dimensão, Sílvio Romero(2) o considera "o melhor poeta dentre os nossos simbolistas"

Essa opinião parece ser partilhada por muitos daqueles que se dedicaram aos estudos de literatura brasileira. Garcia Calderón (3)

(1) - Cf. WELLEK e WARREN - Teoriada Literatura (Trad. de J.P CARMO). Lisboa, Europa-América, (1962) . Cap. XIII.

(2) - ROMERO, Sílvio - História da Literatura Brasileira. 6a. ed. R.J., José Olympio, 1960. Vol. V p. 1685.

(3) - in MURICY, Andrade - Panorama do Movimento Simbolista Brasileiro. R.J., Instituto Nacional do Livro, 1952. Vol. I. p. 104. 
o julga "comparável a Baudelaire"; Roger Bastide (4) o coloca no primeiro plano do simbolismo internacional e Sousa Bandeira (5) o qualifica como "admirável evocador de sons e imagens, capaz de fazer com que as harmonias errantes de nossa língua insuflem alma às palavras que passam, dessa forma, a comandar a deliciosa música dos ritmos"

Cruz e Sousa é, com efeito, o poeta que se volta para uma poesia essencialmente musical (6)

A música verbal que maneja, estilizando diferentes apoios fonéticos, se torna acentuada sobretudo em Broquéis.

Se em Faróis o poeta parace estar caminhando para a visão definitiva do mundo - visão atingida em Ultimos Sonetos - em Broquéis dá-nos ele impressão de estar ainda exercitando-se na técnica preconizada pelo Simbolismo (7)

Nos poemas de Broquéis podemos notar os traços satânicos e lúbricos que haviam caracterizado o decadismo europeu mas é neles que vamos encontrar, de forma mais evidente, a famosa musicalidade, que toca de perto o leitor, fazendo-lhe vibrar as cordas da sensibilidade.

A leitura de qualquer das peças poéticas que compõem a coletânea poderia propor um questão-problema: de que elementos se valeu o poeta para conseguir tão surpreendentes efeitos musicais?

Pareceu-nos que uma análise do estrato fônico do poema intitulado "Lua" - um daqueles em que se patenteia a sonoridade melódica tão magistralmente manejada por Cruz e Sousa - daria a resposta a tal porquê.

Procedemos à análise e alinhamos algumas das observações que pudemos fazer.

Em que pesem os conteúdos semânticos do texto, o universo cósmico apresentado, em sua integração com o mundo psíquico do homem, o vocabulário especialíssimo utilizado - toda a linguagem de Broquéis é revolucionária: se se mantêm traços parnasianos, esses traços acabam por integrar-se num código verbal novo, remetendo-nos a

(4) - id. ibid.

(5) - in PACHECO, Félix - "Discurso de recepção na Academia, seguido de uma resposta de Sousa Bandeira". 1913.

(6) - Cf. PORTELA, Eduardo - "Compreensão de Cruz e Sousa" in Jornal do Comércio (29-03-1959) .

(7) - Cf. BOSI, A. - História Concisa da Literatura Brasileira. 2a. ed. S.P., Cultrix, (1977). pp. 302 e segs. 
significados novos, como afirma A. Bosi (8) - e as imagens insólitas, plásticas, sinestésica e sugestivas que surgem a cada passo, $\tilde{E}$, todavia, no aspecto sonoro que se encontram os elementos que the vão conferir a musicalidade exaltada.

O ritmo dos versos, por exemplo, em lugar de apresentar-se rígido e uniforme como o da poesia parnasiana, sofre um afrouxamento, tornando-se leve e variado. Alternam-se no poema, sem ordem fixa, decassílabos sáficos e heróicos. Constróem-se os decassílabos com dátilos, jambos, troqueus, peons, aparentemente desorganizados, mas que permitem ao ritmo melódico ganhar em variedade sem cair na monotonia que o ritmo uniforme pode imprimir.

A construção assimétrica das estrofes, no tocante à posição das sílabas tônicas secundárias garante ao poema variações melódicas que causam ao leitor uma surpresa constantemente renovada, pois que após a leitura de um verso não se consegue prever o esquema rítmico que vai ser adotado pelo poeta no verso seguinte. A força dos decassílabos heróicos é suavizada constantemente pela doçura dos decassílabos sáficos e as sílabas tônicas secundárias - que muitas vezes assumem um "tonus" importante - se calocam, de verso para verso, em posições diferentes.

A rima que se encontra nos versos de "Lua" é outro aspecto do poema que merece uma análise especial. Construindo o texto com quartetos, Cruz e Sousa utilizou-se de rima cruzada e empregou rima feminina - naturalmente suave - em todo o poema. Â feição dos parnasianos, que procuram evitar a monotonia rítmica, o poeta alterna, nas estrofes, palavras finais com a última vogal bastante diferenciada (vogal aguda e vogal aberta - frias/ neve/ sombrias/ leve; vogal grave e vogal aguda - ondulam/ rios/ tremulam/ calafrios; vogal nasal anterior vogal oral posterior - rendas/ alvuras/ lendas/ alturas; vogal aguda e encontro vocálico fechado - lírios/ geleiras/ círios/ poncheiras); apenas na quarta estrofe do poema, Cruz e Sousa mantém a mesma vogal tônica final nos quatro versos que a Compōem (claridade/ letargo/ imensidade/ amargo)

Não se preocupa o poeta com a riqueza de rima, se entendermos "riqueza" como utilização de palavras rimadas pertencentes a categorias gramaticais diferentes; no entanto, diversamente do que costuma ocorrer com certos poemas românticos, as palavras rimadas se tornam difíceis de serem previstas, uma vez que o poeta se utiliza de um vocabulário refinado - característica dos simbolistas - rimando serenos e trenos, cerúleas e dúlias, geleiras e poncheiras etc.

(8) - id. ibid. 
Mais do que com o ritmo e com a rima, preocupa-se, no entanto, Cruz e Sousa com a utilização de sons expressivos e com a repetição enfática de tais sons.

Predominam no poema as sibilantes surdas e sonoras, que, por sua natureza, conferem ao texto um som semelhante ao de um sopro suave. Entre as sibilantes, porém, avultam, em efeitos aliterantes, consoantes de outras categorias. Encontramos aliterações com oclusivas velares surdas ( $C$ lâmides frescas de brancuras frias), fricativas labiodentais surdas (E fria, fluente, frouxa claridade/Flutua. ), líquidas laterais (Alagam lácteos e fulgentes rios), fricativas labiodentais sonoras ( $V$ agam as virgens), oclusivas bilabiais surdas (Opulências de pérolas e opalas) e chiantes surdas (chama das poncheiras). Em todas as estrofes o poeta trabalha com fonemas nasais (vogais, encontros vacálicos e consoantes), em grande quantidade, chamando-nos a atenção, principalmente, a utilização de tais elementos na terceira e na oitava estrofes (E ondulam névoas, cetinosas rendas/ De virginais, de prônubas alvuras.../Vagam baladas e visões e lendas/ No flórido noivado das alturas. .// Vagam sombras gentis de mortas, vagam/ Em grandes procissões, em grnndes alas,/ Dentre as auréolas, os clarões que alagam/ Opulências de pérolas e opalas)

No poema de Cruz e Sousa rareiam os casos de assonância. Quer parecer-nos entretanto, ter sido uma das preocupações do poeta a elaboração de um texto onde as vogais tônicas das palavras próximas são bastante diferentes (Clâmides frescas de brancuras frias,/ Finíssimas dalmáticas de neve/ Vestem as longas árvores sombrias/ Surgindo a Lua nebulosa e leve) Encontramos exemplos de assonância em "Flutua como as brumas", "gelada e pálida" e palavras assonantes como "finíssimas", "cilicioso", "misticismo"

Há grande número de vocábulos datíllcos e trocaicos (proparoxítonos e paroxítonos terminados por ditongo crescente), que conferem musicalidade bastante especial ao texto (clâmides, finíssimas, dalmáticas, árvores, frígidas, prônubas, flórido, páramos, abóbadas, antífonas, lânguidos, auréolas, pérolas, clorótica, pálida, mórbida e névoas, lácteos, fosforescências, cerúleas, dúlias, etéreos, opulências, magnólias, lírios, círios)

Outro aspecto do estrato fônico do poema, que não poderíamos deixar de focalizar e que contribui de forma decisiva para realçar a sonoridade do mesmo, é a frequência, acima da média, de fonemas sonoros. Sabemos que a língua portuguesa, apesar de contar com apenas doze fonemas vocálicos (e aqui consideramos como fonemas independentes as sete vogais orais - de timbre aberto e fechado e as cincos nasais) contra os dezenove fonemas consonantais, de acor- 
do com avaliação estatística (9), apresenta uma porcentagem de frequiência de $48 \%$ de vogais e $52 \%$ de consoantes, graças aos tipos mais comuns de combinações aceitáveis, ao grande número de encontros vocálicos, ao número relativamente restrito de encontros consonantais, de consoantes finais e de consoantes puras, sem apoio vacálico. E, portanto, uma língua naturalmente sonora. Dos dezenove fonemas consonantais, que possuimos, apenas seis são surdos, enquanto treze são sonoros. Isso não impediu, entretanto, que alguns escritores, como, por exemplo, Euclides da Cunha, tivessem utilizado, em certas passagens, porcentagem maior de consoantes surdas. No célebre período de Os Sertões, "O sertanejo é, antes de tudo, um forte; não tem o raquitismo exaustivo dos mestiços neurastênicos do litoral", vamos encontrar a presença de dezoito consoantes surdas e de vinte e quatro sonoras, o que representa uma porcentagem maior de surdas. De certa forma, este emprego abusivo de surdas contribui para tornar o estilo de Euclides da Cunha áspero e rude. Fato oposto podemos observar na "Lua" de Cruz e Sousa. A porcentagem do emprego de consoantes sonoras ultrapassa, de muito, a de surdas. Há dois versos sem nenhuma consoante surda ("Vagam baladas e visões e lendas" e ó Lua das magnólias e dos lírios") e vários versos onde se nota a presença de uma única consoante surda ("Surgindo a Lua nebulosa e leve", "De virginais, de prônubas alvuras", Vagam as virgens de cismares ermos", "Bóiam nas ondas dos etéreos gelos", "Nas ondas do luar e dos cabelos", "A luz gelada e pálida diluindo") Quando emprega consoantes surdas, muitas vezes o poeta atenua a dureza natural das mesmas, colocando-as em encontros consonantais compostos de surda e líquida ou em sílabas fechadas terminadas por consoantes sonoras. Assim, empregando vinte três vezes a fricativa labiodental surda, em doze dessas vezes coloca-se em encontro consonantal (frescas, frias, frígidas, refração, calafrios, flóridos, frio, fluente, frouxa; flutua, flancos, frio) e em cinco vezes utiliza-a em sílaba terminada por consoante sonora (fulgentes, marfins, enfermos, fulgindo, fulgores). Em menores proporções podemos observar o emprego de oclusivas surdas em encontros formados de surda e líquida. Há encontros iniciados por oclusiva bilabial (prônubas, pratas, procissões, profunda, amplidão, suprema), por dental (tremulam, trenos, entre, tristes, tristeza) e por velar (clâmides, claridade, clarões, clorótica, cristalizou, cristalizada), sempre seguidas de líquiida .

Empregando consoantes sonoras e explorando encontros vocálicos, Cruz e Sousa constrói um texto naturalmente sonoro.

(9) - Cf. PIGNATARI, Décio - Informação. Linguagem. Comunicação. 3a. ed. S.P., Perspectiva, (1969). p. 70. 
Mas contribuem também para a musicalidade do poema as expressivas repetições de palavras, utilizadas pelo poeta. Cruz e Sousa se vale de processos epizêucticos (Névoas e névoas frígidas ondulam), epanalépticos (Vagam sombras gentis de mortas, vagam), polissindéticos (Vagam baladas $e$ visões $e$ lendas) e epimônicos (A tua dor cristalizou-se outrora/ $\mathrm{Na}$ dor profunda mais dilacerada/ $\mathrm{E}$ das dores estranhas, ó Astro, agora/ Es a suprema Dor cristalizada) Utiliza anáfora (Quando ressurges, quando brilhas e amas,/ Quando de luzes a amplidão constelas/ Dás febre e frio, dás nevrose, gelas) e construções pararelas ( $\mathrm{Da}$ vastidão dos páramos serenos,/ Das siderais abóbadas cerúleas// Em grandes procissões, em grandes alas)

Todo esses elementos em conjunto concorrem para que "Lua" seja um poema altamente musical. Não é apenas esse aspecto, entretanto, que lhe confere a beleza que o eterniza. Abstivemo-nos de fazer referência às palavras evocadoras que aí se encontram, aos vocábulos de conotação religiosa, às metáforas, à Metáfora em que todo o texto consiste, às numerosas e expressivas sinestesias (brancuras frias, fria claridade, sonho amargo, lânguidos clarões, luz gelada, fulgores glaciais), às imagens plásticas, aos processos alegóricos, porque foi nossa intenção, tão somente, levantar o problema referente ao estrato sonoro e procurar demonstrar, numa análise fria, os elementos técnicos empregados, consciente ou empiricamente pelo poeta para conferir a esse poema - bem como aos poemas de Broquéis, em geral - a riqueza melódica que foi um dos objetivos perseguidos pelos simbolistas. 